\title{
Effect of Workplace Safety and Health Practices on Employee Commitment and Performance in Steel Manufacturing Companies in Rwanda
}

\author{
Claudine Umugwaneza, Irechukwu Eugenia Nkechi, and Jean Baptiste Mugabe
}

\begin{abstract}
The purpose of this study was to establish the effects of workplace safety and health practices on the employees' commitment and performance in Steel manufacturing companies in Rwanda. The target population of this study was 533 people, which comprised of Managers, Supervisors and employees. A simple random sampling technique was used to select a sample size of 229 respondents from the target population. The data was collected using questionnaires, interview guide and personal observation. The Statistical Package for Social Science (SPSS) software, version 21.0, was used to process data while descriptive statistics such as the means, modes, standard deviation, variances and inferential statistics were used to analyze the data. The findings of the study indicate that most workers are aware of the dangers of occupational health and safety in the workplace. Also the study found that although employees are aware of the occupational health and safety concerns they neglect to put on the Personal Protective Equipments saying that it is too hot. The study concludes that occupational health and safety significantly affects employee commitment and performance. This study recommends that management should insure the workers and provide them with personal protective equipments to minimize workplace injuries and accident. The study also recommends that management provide regular education and training on occupational health and safety concerns to prevent workplace injuries, hence, promote productivity.
\end{abstract}

Index Terms-Employee Commitment, Employee Performance, Health, Safety.

\section{INTRODUCTION}

In the developed world, steel is basically crucial in the construction, infrastructure, automotive and many other sectors. It is also an influential factor in economic growth. Steel industry is known as one of the most challenging work environments and it is highly risky. Employees face many catastrophes and other problems that compromise their safety namely; vibrations, excessive noise, operation on hazardous machinery and many other conditions that may cause injuries. It is in that perspective; steel industries need to ensure safety and health of workers in order to increase the productivity. Casio (1992) argues that machinery and work environment are the main causes of safety risks. In several instances, many employees either by omission or commission are less concerned about security precautions and measures provided by the organizations.

Published on October 12, 2019

Authors are with KIM University. (e-mail: umgclaudy2000@yahoo.fr, irenkechi@gmail.com, mugabejb@gmail.com)
Workplace safety and health is about guaranteeing that humans remain in good physical conditions at work. It is aimed at increasing workers capacity to deliver better. There are different means provided by the International Labor Organization to promote occupational safety and health, namely, codes of practice, international labor standard, dissemination of information and the provision of technical advice through workshop and publication. These means are aimed at increasing the government capacity and its members to prevent workplace accidents and occupational diseases through improving conditions of work. Steenkamp and Van Schoor (2002) mentioned that occupational health and safety is a complex international problem for management and society, and that it must always be a top priority. Everyone must accept part of the responsibility, small mistakes can have a major effect and disasters that not have borders; that is why nations should unite and promote occupational health and safety vigorously to reach the common goal of quick warning, prevention, and protection systems for the employees.

Jilcha and Kitaw, (2016) in their article on occupational health indicates that mortality rate in Sub-Saharan Africa is $21 / 100000$ employees and the accident rate is 16000/100000 workers; about 54000 mortal and about 42 million workers accident happen each year which results in minus 3 days of absenteeism of each employee from work. In Ethiopia, the fatal accident rate is 5596 per year with mortality rate of 21.5/100000 workers and an accident rate of 16426/100000 workers regardless of its poor reporting and data availability precision. Many companies focus on the satisfaction of external customers with their products or services disregarding employee satisfaction and working environment comfort.

In the Rwanda Profile (2012) the number of deaths in 2012 (263 fatalities) varies from six to seven times more than their number in 2007 (41 fatalities). This profile points out that the number of injuries in 2012 is almost equal to four times greater than their number in 2007 and an amount of $1,400,190,808 \mathrm{Frw}$ has been used on occupational hazards for six years (2003-2009/2010). Deficient of health and safety practices at workplace have a massive impact on a business, not only it cans damage the industry and financially cost but also it cans severely hurt workers. Reducing occupation diseases and accidents in Steel Industry in Rwanda would not only improve and save lives of employees but also reduce huge amount pay-out annually by Rwanda Social Security Board to victims of workrelated accidents.

The Rwandan Labor Law of 2018, in chapter 5 states that 
"An employer must ensure the health, safety and welfare in the workplace for employees working in his/her enterprise and for all persons who frequent the enterprise." Employees must work in a good and protected environment so that they can contribute to the development and achievement of organizational goals. In his study Norine et al. (2016) state that the lack of the occupational health and safety management systems led to unexpected compensational costs, by ignoring that prevention is much lower to compensational costs as the case of several projects in Rwanda. According to the Labor Code of Rwanda (2018), Article 80 says that the employer must take the necessary measures for first aid, fire fighting, prevention and the fight against the imminent danger that may arise in his organization. The Health and Safety regulations 1981 oblige employers to provide appropriate equipment, facilities and personal protective to ensure that employees receive immediate attention if they become injures or become ill at work.

Today Rwanda has fifteen Iron and steel industries but only two companies were steel manufacturing companies. This study only focused on steel manufacturing companies that operate in Rwanda which are SteelRwa Industries Ltd and IMANA Steel Rwanda Ltd. Work accident in these steel companies are common; in 2013 at least 10 employees were trapped in hot metal flowing fluid four of them were seriously injure. Another accident occurred in 2018 as a result of an explosion that destroyed the oven, one worker died and three others were seriously injured and in 2019 five employees were injured in an explosion, three of them were severely injured, one employee lost one arm and one leg and two others were slightly injured in Steel Industries Ltd while in 2015 employees were injured in an explosion one of them died, in 2017 they had three accidents; one employee lost one leg, another one were severely injured a steel bars passed through his leg and two employees were trapped in hot metal flowing fluid. In March 2019 the steel bar cut and split the foot of one employee in IMANA Steel Rwanda Ltd.

\section{A. Statement of the Problem}

The research finding of Bucur et al. (2017) has shown that the steel industry has a positive relationship with economic growth of a country. However, the life of industrial workers is full of risks and hazards; their life is prone to accidents and injuries. The most affected employees are those who work in production. Employees in Steel industry are exposed to many hazards at their workplace and this influences their levels of commitment and performance when protection measures are not put in place by their employers. Rwanda as a developing country in the phase of great industrialization, steel companies employ a large number of workers who contribute massively to the construction sector; few measures have been taken to determine the effectiveness of the measures put in place to protect workers against accidents and diseases. With the coming of steel manufacturing industries in Rwanda, the scrap business has grown considerably and has become a revenue generating activity for some people who have engaged in the collection of raw materials; employees of steel industries and some collectors have fallen victim of the unexploded ordnance such as bombs, bullets, shells, grenades and mines collected in the scrap.

Reports from the International Labor Organization and the World Health Organization (ILO 2010; WHO, 2010) reveal that many manufacturing workers encounter workplace accidents that lead to health damage and economic losses. Every 15 seconds a worker dies as a result of an accident at work or illness. Every 15 seconds 153 workers have a work-related accident, every day 6300 people die as a result of occupational accidents and workrelated diseases; more than 2.3 million deaths a year. Each year, 317million accidents happen at work; lot of them provokes prolonged absenteeism of employee at work. The Rwanda Social Security Board reports show that the number of occupation accident and injuries in general is increasing every year; 41 in 2007, 84 in 2008, 114 in 2009, 194 in 2010, 264 in 2011, 263 in 2012, 389 in 2013, 437 in 2014, 516 in 2015, 592 in 2016 and 680 in 2017. Jilcha and Kitaw (2016) showed that developed counties such as North America, Europe and Australia have better plans and budget for occupational safety and health prevention. Therefore, this study sought to establish the effect of workplace safety and health practices on employee performance and commitment in steel manufacturing companies in Rwanda with specific attention on SteelRwa Industries Ltd. and IMANA Steel Rwanda Ltd.

\section{LITERATURE REVIEW}

\section{A. Introduction}

In opening ceremony of the 15 th Word Congress on Occupation Safety and Health in 2011, the Chief of the ILO's Health and Safety program mentioned that approximately two million work-related deaths occur across the world annually, and hundreds of millions of workers suffer from workplace accidents and occupational exposure to hazards. Jilcha and Kitaw (2016) show that in total about one million of workers were injured at work and concluded that approximately 2.4 million of employees in total died every year because of insecure or insanitary conditions of work. Safety and health in workplace are a serious matter that attracts the attention of both the government and the public. Employers are facing more stringent laws to create safe and healthy work environment for their employees. The occupational safety and health administration established in 1970 in USA has publicized many standards explicitly requiring employers to train employees in the safety and health aspects of their jobs (OSHA, 1988). Safety and health at the workplaces have become an essential and a broad element of business viability for employers, Governments, employee syndicates and environmentalists. Occupational safety and health procedures are generally based on directives published by institutions, Nations and International Organizations like BB800NZS 4801/AS; ILO-OSH-2001 and OHSAS 18001. OHSAS has become an important standard to evaluate management processes at organization level.

Everyone at the workplace has legal responsibilities for health and safety according to the OSH legislation. It is 
necessary to consider safety and well-being of employee in the organization in order to boost productivity; hazards must be minimized or eliminated because it negatively impacts employee productivity and commitment which in return affects organizational profitability. Human resource plays the most important role in performing tasks for accomplishing the goal of the organization. It is this human resource which is very important in the success of organization because most of the problems in organizational structure are human and social instead of physical, technical or economic. Ignorance of this fact can cause many losses to the organization. Job performance is the aggregated financial or non-financial value added by the employees in contribution to the fulfillment both directly and indirectly to the organizations' objectives (Motowildo \& Borman, 1993). According to Schermerhorn (1989) cited by Fonkeng (2018) job performance is the quality and quantity attained by an employee or group of employees after accomplishing a given task. Viswesvaran \& Ones (2000), cited by Khuong \& Yen (2016), “Job performance is work behaviors relevant to organizational goals, within the individual's control, measurable, observable and scorable. Fokokunde (2000) considered output as the link between the production of goods and services and the resource inputs (human and material) used in the production of goods and services. Ofoegbu et al. (2013), shows that employees' exposure to occupational hazards, accidents and violence affect productivity. The finding also proves that there is a direct link between output and health and safety practices at work. Therefore to boost productivity, companies must constantly train their employees.

Mohammad and Susanty (2016), and Anggoro et al. (2010) show that there is a significant influence of safety and health on the employee performance; the study confirm that poor or absence of health and safety management decreases employee productivity. According to Sgroi (2015), happiness makes people more productive at work, investing in health promotion is a way of increasing employee performance and reducing absenteeism. Roberto et al. (2014) identified the current status and challenges of global occupational safety and health and the needs for preventive action and suggested regulation to interdict and control transfer of hazards products in developing countries. Gyekye (2010) says that organizations and small industries are still struggling to adopt risk prevention measures in the workplace and most African countries are known for their poor health and safety practices.

The success of implementation of safety and health management system requires commitment of management in order to reduce the risk of injury and illness (Akpan, 2011). Hital (2008) show that leadership mindset and management commitment is the challenge of implementation of $\mathrm{OSH}$ because same organizations consider health and safety practices as a luxury or element necessary for compliance. Grace (2014) concluded that the lack of management commitment and the low cost allocated to employee training and worker's refusal to report minor injuries is the major challenges found in AngloGold Company. Although several studies have been conducted in the field of safety and health of employees in the steel industry in many countries (Omond 2015; Manikandan et al. 2017, Manay et al. 2014; Patmore 2011; Sikpa 2011; Karen and Prussia 2000) showed a positive correlation between safety and health and employee performance in their countries and confirm that the physical environment at work is crucial to employees' performance, satisfaction, health and social relations; however, there is insufficient empirically derived information in Rwanda regarding the promotion of health and safety regulation in the steel manufacturing sector. This gap is astonishing, given that Steel industry in Rwanda is one of these industries where there is a big problem about safety and health. It is on this context that this study became necessary to examine the effect of workplace safety and health practices on employee commitment and performance in the steel manufacturing companies in Rwanda.

\section{B. Theoretical Literature Review}

According to ILO, several theories were developed by researchers from different fields of science and engineering in order to identify, isolate and remove the factors of accidents causations. This study was guided by a number of theories and models; Some of them are Hierarchy of Needs Theory by Abraham Maslow (1943), Health and believe Model by Becker (1974), Accident causation Model (Domino Theory by Heinrich (1931), Ferrell's human factor model by Ferrell (1997) and Peterson's accident/ incident Theory) and Protection and Motivation Theory by Rogers (1983). With such diversity of theories neither is considered right or correct and universally accepted but are necessary even if are not sufficient to use as a reference for understanding accident.

All the above researchers agreed on the factors that contribute to accident which can be classified into three basic causes explained below:

\section{a. Unsafe Acts Working Conditions}

Are the biggest causes of accident all over the world related to work. These can be termed as technical causes; such causes are associated with for example defective plant, equipment's, materials, tools, building etc. They arise from improper or inadequate safety guards on machines, mechanical or construction designs that are defective and unsafe.

\section{b. Unsafe Acts of Employees}

These actions may be the product of ignorance, lack of skills on the part of employees, certain physical defects and wrong attitudes for example: Forgetting to wear or use personal protective, throwing material carelessly on the floor, working at unsafe speeds either (too fast or too slow), lifting improperly and using unsafe equipment's.

\section{c. Act of God/ Chance of Occurrences}

These are events that are no fault of anyone. This type of accident is more or less beyond management's control.

Poor health and safety on workplace can have a massive impact on a business, not only it cans destroy industry and financially cost but also it cans severely injures workers. Accidents are always costly; cause loss directly or indirectly and losses and are both visible and/or invisible. 
The recommended practices for safety and health program by OSH (2016) underlined that "A safety and health management system is a proactive, collaborative process to find and fix workplace hazards before employees are injured or become ill." The objectives of workplace safety and health program are to promote a safe working condition. Secondly it must preserve workers, fellow employee, relatives, client, neighbors and community who are affected by the workplace environment. However, theories say that to adopt a health behavior, people must believe that several threats must occur at any time and know that adopting a health behavior can effectively reduce these threats. And also, people must be convinced of his ability to adopt a behavior that should not cost them much.

\section{RESEARCH METHODOLOGY}

\section{A. Research Design and target population}

The nature of the research design indicates the nature of the research and gives research structure (Flick2012). This research was quantitative and qualitative in nature and adopted descriptive survey to assess the impact of workplace safety and health on employee commitment and performance in steel industries. The researcher used both primary and secondary data. Primary data were obtained through questionnaire, interview and personal observation while secondary data were gathered from the documents available from textbooks, journals and articles, institution's periodic reports, internet and publications.

The target population of this research was 2 Steel manufacturing companies in Rwanda; SteelRwa Industries Ltd and IMANA Steel Rwanda Ltd. The total population comprised of 533 employees of day shift in these Steel Industries especially employees who were directly involved in the production process. The techniques selected for this research was based on both probability and non-probability sampling. Purposive simple random sampling technique was used in selecting sample from the population.

\section{B. Sample Size}

To determine the appropriate sample size for the purpose of data collection Yamane Formula was used for this research

$$
n=\frac{N}{1+N(e)^{2}}
$$

Which gave 229 potential respondents.

\section{Data Collection Instrument}

The main instrument used to collect data for this research was questionnaire and interview. The questionnaires included closed and open-ended questions; and various interrogation techniques regarding job satisfaction, usage of protective devices and history of injuries during work was collected from interviewees. The questionnaires were checked for both validity and reliability.

\section{Data Processing and Analysis}

The collected data from the respondents were coded; organized, entered and processed using the Statistical
Package for the Social Sciences (SPSS). The findings were presented in simple descriptive statistics using some tables, bar charts and percentage to highlight the respondent's perception. A Multiple Regression Model was used to analyze the relationship and establish which among the independent variables are related to the dependent variable.

$$
\mathrm{Y}=\alpha+\beta_{1} X_{1}+\beta_{2} X_{2}+\beta_{3} X_{3}+\mu
$$

\section{RESEARCH FINDINGS AND DISCUSSION}

This chapter covers the results of the study and analysis of the data collected from the respondents. Data is analyzed and evaluated according to research objectives. The data was analyzed using descriptive statistics such as mean scores, percentages, and standard deviations and presented in tables, charts, and graphs. The research targeted all the staff of day shift and the management of Steel manufacturing companies in Rwanda which are SteelRwa Industries Ltd, and IMANA Steel Rwanda Ltd. 229 questionnaires were administered to the sampled respondents, but 195 were properly filled and returned which represented $85.2 \%$ response rate. The findings showed that among 195 respondents, $88.72 \%$ were male and $11.28 \%$ were female depicting that manufacturing company of this nature employs more males than females. The findings obtained showed that $52.8 \%$ had primary school level while $47.2 \%$ had other educational background and the majority of the respondents $69.2 \%$ have been working in their respective organizations for the period ranging from one month to five years.

\section{A. Occupational Hazard Prevention and Employee Commitment and Performance}

The first objective was to ascertain the effect of occupational hazard prevention on employee commitment and performance in steel manufacturing companies in Rwanda. The study sought to establish the health and safety practices by the employees in the company, the causes of the accidents in the company and the actions taken to avoid occurrence of the accident. Moreover, the section shows the extent to which safety measures were put in place in the organization.

TABLE I: OCCUPATIONAL HAZARD PREVENTION AND EMPLOYEE COMMITMENT AND PERFORMANCE

\begin{tabular}{lll}
\hline \hline Statement & Yes & No \\
\hline $\begin{array}{l}\text { I know the right of employee in } \\
\text { relation to Occupation Safety and }\end{array}$ & $43.6 \%$ & $56.4 \%$ \\
Health & & \\
\hline $\begin{array}{l}\text { I always follow safety procedures at } \\
\text { work }\end{array}$ & $36.4 \%$ & $63.6 \%$ \\
\hline $\begin{array}{l}\text { I have sufficient knowledge of } \\
\text { workplace health and safety law }\end{array}$ & $39.5 \%$ & $60.5 \%$ \\
\hline We have a copy of the OSHA at work & $77.4 \%$ & $22.6 \%$ \\
\hline $\begin{array}{l}\text { In our company, we have safety and } \\
\text { health representatives }\end{array}$ & $45.6 \%$ & $54.4 \%$ \\
\hline $\begin{array}{l}\text { Employer gives us necessary skill to } \\
\text { perform our work safely }\end{array}$ & $54.4 \%$ & $45.6 \%$ \\
\hline $\begin{array}{l}\text { Sometimes employee ignores safety } \\
\text { procedure }\end{array}$ & $47.2 \%$ & $52.8 \%$ \\
\hline $\begin{array}{l}\text { My company pays health insurance for } \\
\text { employees }\end{array}$ & $0 \%$ & $100 \%$ \\
\hline
\end{tabular}




\begin{tabular}{llc}
\hline $\begin{array}{l}\text { We are involved in planning and } \\
\text { decision making of safety and health }\end{array}$ & $47.7 \%$ & $52.3 \%$ \\
\hline $\begin{array}{l}\text { Safety meetings are held every three } \\
\text { months }\end{array}$ & $45.6 \%$ & $54.4 \%$ \\
\hline $\begin{array}{l}\text { I know that every employee is } \\
\text { responsible for his own safety at } \\
\text { workplace }\end{array}$ & $54.4 \%$ & $45.6 \%$ \\
\hline $\begin{array}{l}\text { Colleagues in my company ensure the } \\
\text { safety of other workers }\end{array}$ & $60.5 \%$ & $39.5 \%$ \\
\hline \hline
\end{tabular}

The study established that $63.6 \%$ of employees did not follow safety procedures at work, $60.5 \%$ don't have sufficient knowledge of workplace health and safety law, $54.4 \%$ accept that employer gives them necessary skill to perform their work safely, $54.4 \%$ knows that employee is responsible for his own safety at workplace and $60.5 \%$ of employee accept that colleagues ensure the safety of other workers in the company.

Other concerns though on a low scale were the right of employee related to Occupation Safety and Health which represents $43 \%$ of respondents, $45.6 \%$ of respondents said that company has safety and health representative while $54.4 \%$ of respondents did not accept this statement because the safety and health representative doesn't perform their work properly. $47.2 \%$ of employee ignores safety procedure, only $47.7 \%$ of respondents are involved in planning and decision making of safety and health, $45.6 \%$ of respondents intimated that Safety meeting are held every three months. The lowest scale was company pay health insurance for employee which is represented by $(0 \%)$.

\section{B. Personal Protective Equipments (PPE)}

Eighty percent of workers interviewed had been provided with PPE but some factory workers refuse to wear protective equipments saying that the factory is too hot but also some protective equipment are very old. As result this defective protective equipment could potentially pose additional risks to the employee. The study found that helmet and gloves were the most offered protective equipment among all employees of IMANA Steel Rwanda Ltd while Protective closing, helmet and gloves were offered to the employees of SteelRwa Industries Ltd; Failure to provide these PPE meant that there was a risk of being exposed to hazards in the workplace. The study also found that the work procedures were not followed because of work pressure and lack of enforcement.

\section{Perception of Employee Regarding Information and Training Provided by the Employer}

Gibbons (2006) assumes that visible signs and notices must be fixed on all risk places in order to prevent injuries and fatality resulting from workplace accident. The study showed that among the contacted respondents $79.5 \%$ that employer usually told them to be protected and take precaution while performing their work, $18.5 \%$ disagreed with the statement whereas $2.1 \%$ were neutral.

$33.3 \%$ agreed that employer provides safety induction and training to every new employee while $55.4 \%$ disagreed with the statement and $11.3 \%$ were neutral. $53.8 \%$ of respondents agreed with the statement that company provides notices on all safety and health measures while $39.5 \%$ disagreed with the fact only $6.7 \%$ were neutral to the statement.

To reduce the rate of accident at work, provision of safety training, orientation and refresher training to employee is very important. In this study, $47.7 \%$ of contacted respondents agreed with the statement that they received training on how to use personal protective equipment's where $45.1 \%$ disagreed with the statement; while $7.2 \%$ were neutral with the fact; only $29.2 \%$ of respondents agreed with the statement that they are trained to recognize hazards at work while $61.6 \%$ disagreed with the fact. Moreover, $34.4 \%$ of respondents agreed with the statement that they have received first aid training while $60 \%$ disagreed with the statement, and $5.6 \%$ were neutral to the statement. However $60 \%$ of respondents agreed with the statement which says before using new tool, my supervisor regularly informs me procedure of use while $24.6 \%$ of respondents disagreed with the statement and $15.4 \%$ were neutral to the statement. Besides, A good number of contacted respondents $(74.3 \%)$ agreed, with the fact that training received change employee behaviour about how they view safety and health issues only $20 \%$ disagreed with this statement, while $5.6 \%$ were neutral with the fact.

TABLE II: PERCEPTION OF EMPLOYEE REGARDING INFORMATION AND TRAINING PROVIDED BY THE EMPLOYER

\begin{tabular}{|c|c|c|c|c|c|}
\hline Statements & 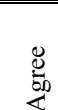 & 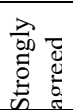 & 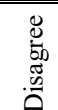 & 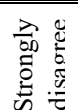 & 宓 \\
\hline $\begin{array}{l}\text { My employer } \\
\text { usually told me to } \\
\text { be protected and } \\
\text { take precaution } \\
\text { when I perform my } \\
\text { work }\end{array}$ & $\begin{array}{l}28 \\
.2 \\
\%\end{array}$ & $\begin{array}{l}51 \\
.3 \\
\%\end{array}$ & $\begin{array}{l}11 \\
.8 \\
\%\end{array}$ & $\begin{array}{l}6 . \\
7 \\
\%\end{array}$ & $\begin{array}{l}2 . \\
1 \\
\%\end{array}$ \\
\hline $\begin{array}{l}\text { Employer provides } \\
\text { safety induction } \\
\text { and training to } \\
\text { every new } \\
\text { employee }\end{array}$ & $\begin{array}{l}9 . \\
7 \\
\%\end{array}$ & $\begin{array}{l}23 \\
.6 \\
\%\end{array}$ & $\begin{array}{l}25 \\
.1 \\
\%\end{array}$ & $\begin{array}{l}30 \\
.3 \\
\%\end{array}$ & $\begin{array}{l}11 \\
.3 \\
\%\end{array}$ \\
\hline $\begin{array}{l}\text { My company } \\
\text { provides notice on } \\
\text { all safety and } \\
\text { health measures }\end{array}$ & $\begin{array}{l}28 \\
.7 \\
\%\end{array}$ & $\begin{array}{l}25 \\
.1 \\
\%\end{array}$ & $\begin{array}{l}23 \\
.6 \\
\%\end{array}$ & $\begin{array}{l}15 \\
.9 \\
\%\end{array}$ & $\begin{array}{l}6 . \\
7 \\
\%\end{array}$ \\
\hline $\begin{array}{l}\text { I received training } \\
\text { on how to use } \\
\text { personal protective } \\
\text { equipment }\end{array}$ & $\begin{array}{l}23 \\
.1 \\
\%\end{array}$ & $\begin{array}{l}24 \\
.6 \\
\%\end{array}$ & $\begin{array}{c}19 \\
.5 \\
\%\end{array}$ & $\begin{array}{l}25 \\
.6 \\
\%\end{array}$ & $\begin{array}{l}7 . \\
2 \\
\%\end{array}$ \\
\hline $\begin{array}{l}\text { I am trained to } \\
\text { recognize hazards } \\
\text { at work }\end{array}$ & $\begin{array}{l}9 . \\
7 \\
\%\end{array}$ & $\begin{array}{c}19 \\
.5 \\
\%\end{array}$ & $\begin{array}{c}34 \\
.9 \\
\%\end{array}$ & $\begin{array}{c}26 \\
.7 \\
\%\end{array}$ & $\begin{array}{l}9 . \\
2 \\
\%\end{array}$ \\
\hline $\begin{array}{l}\text { I received first aid } \\
\text { training }\end{array}$ & $\begin{array}{c}23 \\
.1 \\
\% \\
\end{array}$ & $\begin{array}{l}11 \\
.3 \\
\% \\
\end{array}$ & $\begin{array}{c}34 \\
.9 \\
\%\end{array}$ & $\begin{array}{c}25 \\
.1 \\
\% \\
\end{array}$ & $\begin{array}{l}5 . \\
6 \\
\%\end{array}$ \\
\hline $\begin{array}{l}\text { Before using new } \\
\text { tool, my supervisor } \\
\text { regularly informs } \\
\text { me procedure of } \\
\text { use }\end{array}$ & $\begin{array}{c}29 \\
.2 \\
\%\end{array}$ & $\begin{array}{c}30 \\
.8 \\
\%\end{array}$ & $\begin{array}{c}10 \\
.8 \\
\%\end{array}$ & $\begin{array}{c}13 \\
.8 \\
\%\end{array}$ & $\begin{array}{c}15 \\
.4 \\
\%\end{array}$ \\
\hline $\begin{array}{l}\text { Training received } \\
\text { change my } \\
\text { behavior about how } \\
\text { I view safety and } \\
\text { health issues }\end{array}$ & $\begin{array}{c}36 \\
.4 \\
\%\end{array}$ & $\begin{array}{c}37 \\
.9 \\
\%\end{array}$ & $\begin{array}{c}12 \\
.8 \\
\%\end{array}$ & $\begin{array}{l}7 . \\
2 \\
\%\end{array}$ & $\begin{array}{l}5 . \\
6 \\
\%\end{array}$ \\
\hline
\end{tabular}


D. Effects of Safety and Health Management Systems and Employee Commitment and Performance

The second objective was to determine the effects safety and health management system and employee commitment and performance in steel manufacturing companies. The research question sought to establish the effects of safety and health management system on the employee performance and commitment when there is lack of leadership management, irregular safety and healthcare programs and organizational safety culture constantly followed and implemented.

The following table showed that $62.5 \%$ of respondents agreed that company encourages employees to report and record accident that occur at work while $29.7 \%$ disagreed and $7.7 \%$ remained neutral.

In addition, among the respondents, $80 \%$ agreed that they have a formal safety and health reporting in the company, while $14.9 \%$ of respondents disagreed with the statement, only $5.1 \%$ remained neutral. Also $42.5 \%$ of respondents agreed that the company assess periodically safety and health standards at workplace, $51.8 \%$ disagreed while $6.7 \%$ was neutral.

Among the contacted respondents, $29.8 \%$ of respondents agreed that hazard assessment is conducted jointly by the management and employee representative while $63.6 \%$ disagreed with the statement $6.7 \%$ were neutral.

Lastly, $50.2 \%$ of respondents agreed that inspector impose penalties when the employer is not compliant while $41.6 \%$ disagreed and $6.7 \%$ were neutral with the fact.

TABLE III: HEALTH MANAGEMENT SySTEMS AND EMPLOYEE COMMITMENT AND PERFORMANCE

\begin{tabular}{|c|c|c|c|c|c|}
\hline Statements & 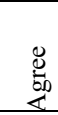 & 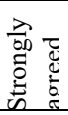 & 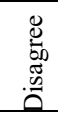 & 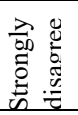 & 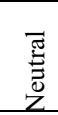 \\
\hline $\begin{array}{l}\text { My company } \\
\text { encourages } \\
\text { employees to } \\
\text { report and record } \\
\text { accident that occur } \\
\text { at work }\end{array}$ & $\begin{array}{c}33 \\
.8 \\
\%\end{array}$ & $\begin{array}{c}28 \\
.7 \\
\%\end{array}$ & $\begin{array}{c}16 \\
.9 \\
\%\end{array}$ & $\begin{array}{c}12 \\
.8 \\
\%\end{array}$ & $\begin{array}{l}7 . \\
7 \\
\%\end{array}$ \\
\hline $\begin{array}{l}\text { We have a formal } \\
\text { safety and health } \\
\text { reporting in my } \\
\text { company }\end{array}$ & $\begin{array}{c}28 \\
.7 \\
\%\end{array}$ & $\begin{array}{c}51 \\
.3 \\
\%\end{array}$ & $\begin{array}{l}7 . \\
7 \\
\%\end{array}$ & $\begin{array}{l}7 . \\
2 \\
\%\end{array}$ & $\begin{array}{l}5 . \\
1 \\
\%\end{array}$ \\
\hline $\begin{array}{l}\text { My company } \\
\text { assess periodically } \\
\text { health and safety } \\
\text { standards in the } \\
\text { workplace }\end{array}$ & $\begin{array}{c}24 \\
.6 \\
\%\end{array}$ & $\begin{array}{c}16 \\
.9 \\
\%\end{array}$ & $\begin{array}{l}31 \\
.8 \\
\%\end{array}$ & $\begin{array}{l}20 \\
\%\end{array}$ & $\begin{array}{l}6 . \\
7 \\
\%\end{array}$ \\
\hline $\begin{array}{l}\text { Hazard assessment } \\
\text { is conducted } \\
\text { jointly by the } \\
\text { management and } \\
\text { employee } \\
\text { representative }\end{array}$ & $\begin{array}{l}15 \\
.4 \\
\%\end{array}$ & $\begin{array}{c}14 \\
.4 \\
\%\end{array}$ & $\begin{array}{c}35 \\
.9 \\
\%\end{array}$ & $\begin{array}{c}27 \\
.7 \\
\%\end{array}$ & $\begin{array}{l}6 . \\
7 \\
\%\end{array}$ \\
\hline $\begin{array}{l}\text { Inspector impose } \\
\text { penalties when the } \\
\text { employer is not } \\
\text { compliant }\end{array}$ & $\begin{array}{c}28 \\
.7 \\
\%\end{array}$ & $\begin{array}{c}21 \\
.5 \\
\%\end{array}$ & $\begin{array}{c}26 \\
, 2 \\
\%\end{array}$ & $\begin{array}{c}16 \\
.4 \\
\%\end{array}$ & $\begin{array}{l}7 . \\
2 \\
\%\end{array}$ \\
\hline
\end{tabular}

E. Satisfaction Levels on Management Effort on Occupational Health and Safety

Fig.1. shows that $62(32 \%)$ of the respondents were satisfied with the effort of management in improving occupational health and safety of the workers in the company. However, 133 (68\%) of the respondents were not satisfied; the majority of employees reported some safety and health arrangements that have not been implemented for a long period of time despite being reported and several reminders. A case in point that the researcher observed was lack of bag filters to trap smoke and dust in the factory, to change old safety shoes, to change old gloves and protective clothing, cutting bushes around the factory, to provide employee contract, health insurance and increase salary.

These problems have been reported year after year and no actions have been taken. The statistics results show that there is a significant relationship between the management support on the occupational health and safety and the occupational health and safety practices raised by the employees in the company. This is to mean that, an increase in management support on the occupational health and safety in the company would lead to a decrease in occupational safety and health concerns in the organization.

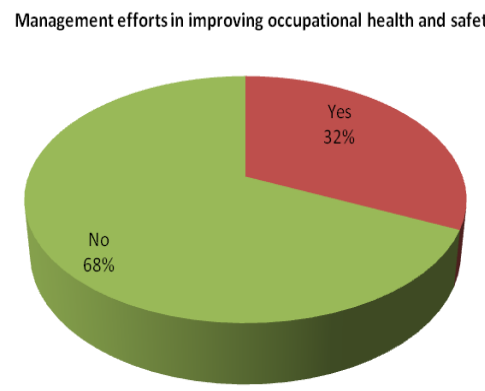

Fig.1. Perception of employee Management Effort

\section{F. Effects of Safety and Health Management Systems and Employee Commitment and Performance}

$72.3 \%$ of respondents said that lack of leadership management, irregular safety and healthcare programs and organizational safety culture led to decreased productivity while $65.1 \%$ of the respondents, showed that lack of leadership management, irregular safety and healthcare programs and organizational safety culture led to increased accident because employees are not feeling safe. On the other hand, $53.8 \%$ indicated that lack of leadership management, irregular safety and healthcare programs and organizational safety culture led to increased absenteeism while $56.9 \%$ of the respondents revealed that the occupational hazard and accidents led to increased hospital bills and increased life insurance claims. The findings are in line with those of McCunney (2001) who revealed that workplace health risks and employees' inability to participate in health promotion programs are linked with higher rates of absenteeism and low productivity.

TABLE IV: EFFECTS OF SAFETY AND HEALTH MANAGEMENT SySTEMS AND EMPLOYEE COMMITMENT AND PERFORMANCE

\begin{tabular}{lll}
\hline \hline \multirow{2}{*}{ Effects } & \multicolumn{2}{l}{ Frequency } \\
\cline { 2 - 3 } & YES & NO \\
\hline Lack of leadership & 127 & 68 \\
management, irregular safety & $(65.1$ & $(34.9$ \\
and healthcare programs and & $\%)$ & $\%)$ \\
organizational safety culture & & \\
\hline \hline
\end{tabular}




\begin{tabular}{|c|c|c|}
\hline lead to increased accident & & \\
\hline $\begin{array}{l}\text { Lack of leadership } \\
\text { Management, irregular safety } \\
\text { and healthcare programs and } \\
\text { organizational safety culture } \\
\text { lead to increased absenteeism }\end{array}$ & $\begin{array}{l}105 \\
(53.8 \\
\%)\end{array}$ & $\begin{array}{l}90 \\
(46.2 \\
\%)\end{array}$ \\
\hline $\begin{array}{l}\text { Lack of leadership } \\
\text { management, irregular safety } \\
\text { and healthcare programs and } \\
\text { organizational safety culture } \\
\text { lead to decreased productivity }\end{array}$ & $\begin{array}{l}141 \\
(72.3 \\
\%)\end{array}$ & $\begin{array}{l}54 \\
(27.7 \\
\%)\end{array}$ \\
\hline $\begin{array}{l}\text { Lack of leadership } \\
\text { management, irregular safety } \\
\text { and healthcare programs and } \\
\text { organizational safety culture } \\
\text { lead to increased hospital bills }\end{array}$ & $\begin{array}{l}111 \\
(56.9 \\
\%)\end{array}$ & $\begin{array}{l}84 \\
(43.1 \\
\%)\end{array}$ \\
\hline
\end{tabular}

G. Level of Satisfaction on Safety and Health Practices Implement in the workplace

Most employees are not satisfied with safety and health practices in their workplace; in total $66.2 \%$ of the respondents reported that they were dissatisfied, while $26.6 \%$ indicated that they were satisfied only $7.2 \%$ were neutral. From the open ended questions asked, it was discovered that workers complained that they do not have clean water for drinking while performing their job.

According to the interview and observation few workers were satisfied while many of them complained of lack of implementation of the recommended actions, lack of training and sufficient personal protective equipment. Workers exposed to high temperature must be given enough water and if possible juice or milk according to article 41 of Ministerial orders N0 2/17/05/2012 determining conditions for OSH.

The findings above show that workers environment is an important component that determines the workers satisfaction. This is supported by the results of a study conducted by Mears (1999) on behalf of Robert Half International Inc. who showed that the work environment has become one of the most critical factors in keeping an employee satisfied in today's working environment. Also, the findings concur with findings of Kimani (2011) who conducted a study on Occupational health and safety and revealed that the need to create a favorable environment for the workers by putting in place good safety measures in order to increase productivity.

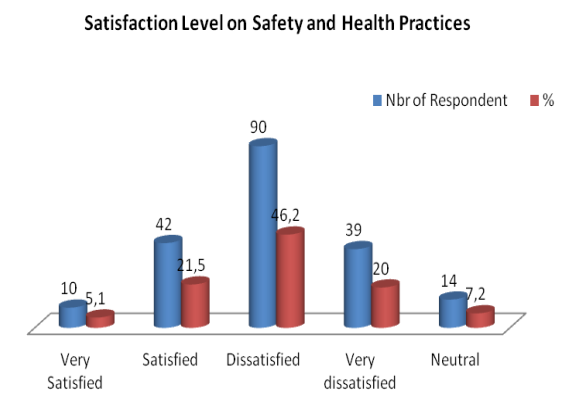

Fig.2. Satisfaction Level with Safety and Health Practices

H. Way to Improve Health and Safety in the workplace

Providing and maintaining a safe work environment is very important to avoid accident and illnesses. Factory workers who work under hazardous conditions without insurance scheme complained about lack of contract and payment of incidental leave because they are scared that the employer does not pay RSSB contribution on their behalf.

Employee performance is better when they are satisfied with their salary package, feel safe for their work and satisfied with the reward system. Awan and Asghar (2014) confirmed a positive relationship between job satisfaction and employee performance as regards to the salary package, security level and the reward system. With regard to this issue, respondent suggested different ways to improve safety and health in the workplace.

TABLE V: WAY TO IMPROVE HEALTH AND SAFETY IN THE WORKPLACE

\begin{tabular}{lll}
\hline \hline Suggestions & YES & NO \\
\hline Provide work contract & $\begin{array}{l}141 \\
(72.3 \%)\end{array}$ & $\begin{array}{l}54 \\
(27.7 \%)\end{array}$ \\
\hline $\begin{array}{l}\text { Provide new Personal } \\
\text { Protective Equipments }\end{array}$ & $\begin{array}{l}178 \\
(91.2 \%)\end{array}$ & $\begin{array}{l}17 \\
(8.8 \%)\end{array}$ \\
\hline $\begin{array}{l}\text { Provide weekly rest and } \\
\text { annual leave }\end{array}$ & $\begin{array}{l}195 \\
(100 \%)\end{array}$ & $0(0 \%)$ \\
\hline Increase salary & $\begin{array}{l}189 \\
(96.9 \%)\end{array}$ & $6(3.1 \%)$ \\
\hline Give us Trainings & $\begin{array}{l}126 \\
(64.6 \%)\end{array}$ & $\begin{array}{l}69 \\
(35.4 \%)\end{array}$ \\
\hline Overtime compensation & $\begin{array}{l}171 \\
(87.6 \%)\end{array}$ & $\begin{array}{l}24 \\
(12.4 \%)\end{array}$ \\
\hline Provide insurance & $\begin{array}{l}195 \\
(100 \%)\end{array}$ & $0(0 \%)$ \\
\hline Provide incidental leave & $\begin{array}{l}111 \\
(56.9 \%)\end{array}$ & $\begin{array}{l}84 \\
(43.1 \%)\end{array}$ \\
\hline Pay RSSB Contribution & $82(42 \%)$ & $\begin{array}{l}113 \\
(58 \%)\end{array}$ \\
\hline Respect & $\begin{array}{l}107 \\
(54.8 \%)\end{array}$ & $\begin{array}{l}88 \\
(45.2 \%)\end{array}$ \\
\hline \hline
\end{tabular}

I. Compensation Management and Employee Commitment and Performance

In response to these aspects $15.8 \%$ of respondents agreed that in case of accident, employee gets compensation according to the law, $12.7 \%$ of respondents strongly agreed, $25.1 \%$ disagreed, $31.2 \%$ strongly disagreed while $15.2 \%$ were neutral. Among the contacted respondents, $25.1 \%$ of respondents agreed that case of permanent partial disablement employees get his compensation and be fired, $42.1 \%$ of responding strongly agreed, $15.4 \%$ disagreed, $11.3 \%$ strongly disagreed while $6.2 \%$ were neutral.

TABLE VI: COMPENSATION MANAGEMENT AND EMPLOYEE COMMITMENT AND PERFORMANCE

\begin{tabular}{|c|c|c|c|c|c|}
\hline Statements & $\begin{array}{l}\stackrel{8}{0} \\
\frac{0}{L}\end{array}$ & 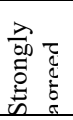 & 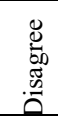 & 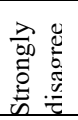 & $\begin{array}{l}\bar{\pi} \\
\stackrel{\Xi}{0} \\
Z\end{array}$ \\
\hline $\begin{array}{l}\text { In case of accident, } \\
\text { employee get } \\
\text { compensation } \\
\text { according to the } \\
\text { law }\end{array}$ & $\begin{array}{c}15 \\
.8 \\
\%\end{array}$ & $\begin{array}{c}12 \\
.7 \\
\%\end{array}$ & $\begin{array}{l}25 \\
.1 \\
\%\end{array}$ & $\begin{array}{c}31 \\
.2 \\
\%\end{array}$ & $\begin{array}{l}15 \\
.2 \\
\%\end{array}$ \\
\hline $\begin{array}{l}\text { In case of } \\
\text { permanent partial } \\
\text { disablement } \\
\text { employees get his } \\
\text { compensation and } \\
\text { be fired }\end{array}$ & $\begin{array}{c}25 \\
.1 \\
\%\end{array}$ & $\begin{array}{c}42 \\
.1 \\
\%\end{array}$ & $\begin{array}{l}15 \\
.4 \\
\%\end{array}$ & $\begin{array}{l}11 \\
.3 \\
\%\end{array}$ & $\begin{array}{l}6 . \\
2 \\
\%\end{array}$ \\
\hline
\end{tabular}




\section{J. Perception of Employee Regarding Working Environment as indirect payment}

The results show that $66.1 \%$ of respondents disagreed with the fact that they are satisfied with the health and safety practices implemented in their workplace, $82.1 \%$ of respondents agreed that the productivity will be affected positively by a good and comfortable working environment, $75.3 \%$ of respondents agreed that the Management give a quick response to safety concern, also $56.5 \%$ disagreed that they receive refresher training on safety and health every year or regularly.

Furthermore, among the contacted respondents, $70.2 \%$ of respondents agreed that favorable environmental conditions provided at work increase their productivity. And $60 \%$ of respondents agreed that they are satisfied with the level of hygiene at their workplace. Lastly, among the contacted respondents, $65.1 \% \quad 6$ agreed that the chemical and poisoning substance are clearly marked and kept in a safe room.

During site visit by one of the researchers, smoke and dust were observed emanating from some of the machineries; high temperatures were felt in the factory, especially the kiln which has a 3000C and insufficiency of personal protective equipment. All these concerns were seen to influence the safety of the workers and the accident that occur in the company.

TABLE VII: PERCEPTION OF EMPLOYEE REGARDING WORKING ENVIRONMENT AS DIRECT PAYMENT

\begin{tabular}{|c|c|c|c|c|c|}
\hline Statements & 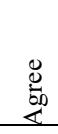 & 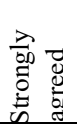 & 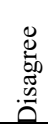 & 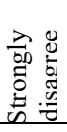 & $\begin{array}{l}\bar{\pi} \\
\stackrel{\pi}{0} \\
z\end{array}$ \\
\hline $\begin{array}{l}\text { I am satisfied with } \\
\text { the health and } \\
\text { safety practices } \\
\text { implemented in my } \\
\text { workplace because } \\
\text { it will make me } \\
\text { feel safe }\end{array}$ & $\begin{array}{l}21 \\
.5 \\
\%\end{array}$ & $\begin{array}{l}5 . \\
1 \\
\%\end{array}$ & $\begin{array}{l}46 . \\
2 \\
\%\end{array}$ & $\begin{array}{l}20 \\
\%\end{array}$ & $\begin{array}{l}7 . \\
2 \\
\%\end{array}$ \\
\hline $\begin{array}{l}\text { My productivity } \\
\text { will be affected } \\
\text { positively by a } \\
\text { good and } \\
\text { comfortable } \\
\text { working } \\
\text { environment }\end{array}$ & $\begin{array}{l}40 \\
\%\end{array}$ & $\begin{array}{l}42 \\
.1 \\
\%\end{array}$ & $\begin{array}{l}7 . \\
2 \\
\%\end{array}$ & $\begin{array}{l}6 . \\
2 \\
\%\end{array}$ & $\begin{array}{l}4 . \\
6 \\
\%\end{array}$ \\
\hline $\begin{array}{l}\text { Management give a } \\
\text { quick response to } \\
\text { safety concern }\end{array}$ & $\begin{array}{l}29 \\
.7 \\
\%\end{array}$ & $\begin{array}{l}45 \\
.6 \\
\%\end{array}$ & $\begin{array}{l}1 \\
2 \\
. \\
3 \\
\%\end{array}$ & $\begin{array}{l}6 . \\
4 \\
\%\end{array}$ & $\begin{array}{c}6 \\
\%\end{array}$ \\
\hline $\begin{array}{l}\text { We receive } \\
\text { refresher training } \\
\text { on safety and } \\
\text { health every year } \\
\text { or regularly }\end{array}$ & $\begin{array}{l}21 \\
\%\end{array}$ & $\begin{array}{l}17 \\
.9 \\
\%\end{array}$ & $\begin{array}{l}4 \\
2 \\
. \\
1 \\
\%\end{array}$ & $\begin{array}{l}14 \\
.4 \\
\%\end{array}$ & $\begin{array}{l}4 . \\
6 \\
\%\end{array}$ \\
\hline $\begin{array}{l}\text { Favorable } \\
\text { environmental } \\
\text { conditions } \\
\text { provided at work } \\
\text { will increase my } \\
\text { productivity }\end{array}$ & $\begin{array}{l}29 \\
.2 \\
\%\end{array}$ & $\begin{array}{l}41 \\
\%\end{array}$ & $\begin{array}{l}13 . \\
3 \\
\%\end{array}$ & $\begin{array}{c}5 . \\
1 \\
\%\end{array}$ & $\begin{array}{l}11 . \\
3 \%\end{array}$ \\
\hline $\begin{array}{l}\text { I am satisfied with } \\
\text { the level of } \\
\text { hygiene at my }\end{array}$ & $\begin{array}{l}27 \\
.7 \\
\%\end{array}$ & $\begin{array}{l}32 \\
.3 \\
\%\end{array}$ & $\begin{array}{l}2 \\
3 \\
6\end{array}$ & $\begin{array}{l}11 \\
.3 \\
\%\end{array}$ & $\begin{array}{l}5 . \\
1 \\
\%\end{array}$ \\
\hline
\end{tabular}

\begin{tabular}{lccccc}
\hline \hline workplace & \multicolumn{5}{c}{$\%$} \\
\hline Chemical and & & & & & \\
poisoning & 31 & 33 & 8. & 10 & 15. \\
substance are & .3 & .8 & 7 & .8 & $4 \%$ \\
clearly marked and & $\%$ & $\%$ & $\%$ & $\%$ & \\
kept in a safe room & & & & & \\
\hline \hline
\end{tabular}

\section{K. Incidental Leave}

$52.8 \%$ of respondents said that when minor accidents occur the Company Nurse treats them, allows them to go home and resume the next day, while $47.1 \%$ said that they are allowed to take incidental leave between one to two days payable depending on the gravity of the injury. Majority of respondents disclosed that when accident happens they are not paid for incidental leave because they are casual staff. In that case injured employee is required to come every day to see the Nurse in order to get incidental compensation.

\begin{tabular}{llll}
\multicolumn{4}{c}{ TABLE VIII: INCIDENTAL LEAVE } \\
\hline \hline Question & 0 day & 1 to 2days & Total \\
\hline How many days do & 103 & 92 & 195 \\
$\begin{array}{l}\text { you stay at home } \\
\text { when you get injured }\end{array}$ & $(52.8 \%)$ & $(47.1 \%)$ & \\
at work? & & & \\
\hline \hline
\end{tabular}

\section{Regression Analysis}

A multivariate regression model was applied to determine the relationship between workplace safety and health practices and employee commitment and performance in IMANA Steel Rwanda Ltd and SteelRwa Industries Ltd.

From the regression model summary the value of adjusted $\mathrm{R}^{2}$ is 0.798 . This implies that Compensation Management, Safety and Health Management System and Occupational Hazards Prevention (independent variables) explain $79.8 \%$ of performance and commitment of employees; the remaining $20.2 \%$ would be explained by other variables not included in the study.

TABLE IX: MODEL SUMMARY

\begin{tabular}{|c|c|c|c|c|}
\hline Model & $\mathrm{R}$ & $\begin{array}{l}\mathrm{R} \\
\text { Square }\end{array}$ & $\begin{array}{l}\text { Adjusted } \\
\text { R Square }\end{array}$ & $\begin{array}{l}\text { Std. Error of } \\
\text { the Estimate }\end{array}$ \\
\hline 1 & $0.932 \mathrm{a}$ & 0.865 & 0.798 & 0.130 \\
\hline \multicolumn{5}{|c|}{$\begin{array}{l}\text { a. Predictors: (Constant), Compensation } \\
\text { Management, Safety and Health Management } \\
\text { System and Occupational Hazards Prevention }\end{array}$} \\
\hline
\end{tabular}

\section{M. $A N O V A^{a}$}

The ANOVA results for indicate that the significance of the $\mathrm{F}$ is 0.00 which is less than 0.05 . This implies that there is a positive significant relationship between Occupational hazards prevention, Safety and health management system and Compensation management versus employee commitment and performance. Hence, the model is a good fit for the data.

TABLE X: ANOVA

\begin{tabular}{|c|c|c|c|c|}
\hline Model & $\begin{array}{l}\text { Sum of } \mathrm{df} \\
\text { Squares }\end{array}$ & $\begin{array}{l}\text { Mean } \\
\text { Square }\end{array}$ & $\mathrm{F}$ & Sig. \\
\hline
\end{tabular}




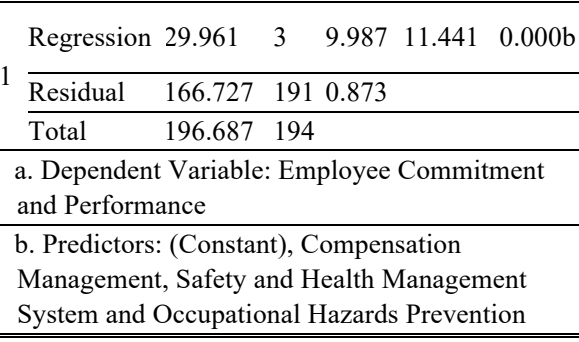

\section{N. Coefficient Results}

From the regression analysis, the following regression equation was established

$$
\mathrm{Y}=1.536+1.625 X_{1}-0.744 X_{2}-0.566 X_{3}
$$

From the above regression model, holding all variables constant, employee commitment and performance would be at a unit of 1.536 Further, a unit increase occupational hazards prevention would cause an increase in performance and commitment of employee by a factor of 1.625 and a unit increase in safety and health management system would cause to a decrease in commitment and performance of employees by a factor of 0.744 , a unit increase in compensation management would lead to a decrease in performance and commitment of employee by a factor of 0.566 . Both the relationships are significant as shown by the $P$ value $(p=0.000<0.05), \quad(p=0.001<0.05)$ and $(\mathrm{p}=0.045<0.05)$.

The findings of this study confirm that strong relationship between employee commitment and performance, and occupational hazards prevention, safety and health management system and compensation management exists. This result is in line with the findings of Manikandan et al. (2017), Omond (2015), Mohammad and Susanty (2016), Manay et al. (2014); Patmore (2011); Sikpa (2011) Anggoro et al. (2010) who showed a positive correlation between safety and health and employee performance as well as Sgoi 2015, Awan and Asghar (2014) who confirmed a positive relationship between job satisfaction and employee performance as regards to the salary package, security level and the reward system.

\begin{tabular}{|c|c|c|c|c|c|}
\hline \multirow{2}{*}{\multicolumn{2}{|c|}{ Model }} & $\begin{array}{l}\text { Unstan } \\
\text { zed } \\
\text { Coeffic }\end{array}$ & $\begin{array}{ll}\text { dardi- } & \begin{array}{l}\text { Standardi- } \\
\text { zed }\end{array} \\
\text { cients } & \begin{array}{l}\text { Coefficien } \\
\text { ts }\end{array}\end{array}$ & \multirow[t]{2}{*}{$\mathrm{T}$} & \multirow[t]{2}{*}{ Sig. } \\
\hline & & \multicolumn{2}{|c|}{$\begin{array}{ll}\text { B } & \begin{array}{l}\text { Std. } \\
\text { Error Beta }\end{array} \\
\end{array}$} & & \\
\hline \multirow{5}{*}{1} & (Constant) & 1.536 & 0.222 & 6.906 & 0.000 \\
\hline & $\begin{array}{l}\text { Occupatio } \\
\text { nal } \\
\text { Hazards } \\
\text { Prevention } \\
\end{array}$ & 1.625 & 0.3060 .771 & 5.303 & 0.000 \\
\hline & $\begin{array}{l}\text { Safety and } \\
\text { Health } \\
\text { Manageme } \\
\text { nt System }\end{array}$ & $e^{-0.744}$ & $0.210-0.369$ & -3.538 & 30.001 \\
\hline & $\begin{array}{l}\text { Compensa } \\
\text { ion } \\
\text { Manageme } \\
\text { nt }\end{array}$ & $e^{-0.566}$ & $0.281-0.252$ & -2.017 & 70.045 \\
\hline & $\begin{array}{l}\text { Dependent } \\
\text { Performance }\end{array}$ & Variab & le: Employee Con & mmitme & ent and \\
\hline
\end{tabular}

\section{SUMMARY OF FINDINGS, CONCLUSION AND RECOMMENDATIONS}

\section{A. Summary of the Findings}

This study sought to establish the effect of workplace safety and health practices on employee commitment and performance in steel manufacturing companies of Rwanda. It was found that workplace safety and health practices such as occupational hazards prevention, safety and health management system and compensation management at IMANA Steel Rwanda Ltd and SteelRwa Industries Ltd influence employee commitment and performance. This was confirmed by a strong correlation where R2 was 0.798 showing that there was $79.8 \%$ of the variation in employee commitment and performance which is accounted for by the combined effect of occupational hazards prevention, safety and health management system and compensation management.

However, the findings show that $63.6 \%$ of respondents did not follow safety procedures at work due to work pressure and lack of enforcement, $60.5 \%$ of respondents do not have sufficient knowledge of workplace health and safety law and $56.4 \%$ do not know the right of employee related to occupational safety and health. Also the study reveals that $68 \%$ of respondents were not satisfied with the effort of management in improving occupational health and safety of workers and $66.1 \%$ of respondents were not satisfied with the safety and health practices implemented at their workplace where they complained about lack of contract and payment of incidental leave and $100 \%$ of respondents did not have health insurance. Lastly majority of contacted respondents $56.3 \%$ disclosed that when accident happens they are not paid according to the law because they are casual workers.

\section{B. Conclusion}

The following conclusions were made based on the study findings after assessing the effect of workplace safety and health practices on employee commitment and performance in steel manufacturing companies in Rwanda. The result of this study indicates that exposure of workers to occupational hazards affects their commitment and performance. Education, safety training and hazards assessment are the key elements in order to reduce accidents and injuries at work. The study concludes that occupational health and safety significantly affects employee commitment and performance in IMANA Steel Rwanda Ltd and SteelRwa Industries Ltd. Efforts have been made to establish and implement an occupational health and safety policy. However, there can be no effective occupational health and safety policies if employers and employees do not fulfill their respective responsibilities.

The study confirms that poor or absence of health and safety management decreases employee productivity. $70.2 \%$ of the respondents agreed that favorable environment conditions provided at work increase productivity while $66.2 \%$ were not satisfied with the health and safety practices implemented at their workplace. The study concludes that exposure to smoke and dust, high temperatures, noisy environment, and failure to use personal protective equipment were the major occupational 
health and safety concerns in the company. However, the company must put in place measures to improve occupational health and safety in the company. Some of the measures include supervision and safety management, constant review of health and safety practices and regular training of employees on safety to improve occupational health and safety concerns in the company.

The company has an occupational health and safety policy. This policy can be effective in reducing occupational hazards and improving safety among employees in the company. However, implementation seems to be a problem. Accidents are costly to the affected worker and the organization; increased accidents lead to increased absenteeism and increased hospital bills. Therefore, every effort must be done to avoid accident in the workplace.

\section{Recommendation}

The following recommendations were made on the basis of the findings of the study:

To present the necessary information, instruction, training and supervision the management must take into account the employee's literacy level and other circumstances. Training and education in safety and health need to be improved so that workers know their rights and obligations; The management of IMANA Steel Rwanda Ltd and SteelRwa Industries Ltd should organize and deliver regular trainings, workshops, seminars and refresher trainings on health and safety at work, to keep records of safety and health concerns and to publish documents on safety and many other measure to instill safety awareness in the minds of workers.

Some accidents could have been avoided if effective supervision were carried out during the execution of duties at the workplace. Management must share information about hazard and risk with other employers, including those who visit or live around the factory, other occupants of the site and everyone who will come to the factory. Appropriate dissemination of risk information is essential to ensure a safe and healthy working environment. Workers must be properly informed about the risks and dangers inherent in their work at the workplace. Through education some of these accidents could be minimized or even eliminated.

Management should provide protective equipment to new workers and changes the old one as well as invest in heatresistant personal protective clothing for warm environment. Management should also put in place a regular monitoring team to verify that employees are putting on the protective equipment they have been given before performing their duties and strictly observe the safety measures put in place in order to prevent accidents and put in place internal rules and regulations governing working condition.

The study recommends that the management of IMANA Steel Rwanda Ltd and SteelRwa Industries Ltd should establish a special safety committee to deal with all health and safety related issues. The special safety committee should be responsible for studying accident trends with a view to proposing corrective measures, reviewing safety reports and making proposals to avoid accidents, also it should make proposals regarding new or revised safety procedures. Employees must understand that safety and health practices are the responsibility of both management and employee which will greatly contribute to the safety of work environment. Management should provide and maintain workplace facilities and systems that are adequate, safe and without risk to health.

Factory workers who work under hazardous conditions without insurance scheme complained about lack of contract and payment of incidental leave and other compensation for work-related diseases and injuries. The study recommends that management should provide work contract and health insurance to all employees. Management should also provide enough and clean water to the factory workers and compensate injured worker according to the law. Beside that the study recommends that management should provide to the workers weekly rest and annual leave in order to reduce stress and avoid accidents.

Lastly, the government and other regulatory agencies should have monitoring teams in place to periodically review whether steel manufacturing companies are complying with safety and health practices set out in the Labor Code.

\section{REFERENCES}

Amelia Bucur et al. (2017). Economic and qualitative determinants of the world steel production: Romania

ACSNI Human Factors Study Group (1993): Organizing for Safety. HSE Books

Afande, O. F. (2013). Effects of strategic management practices on performance of financial institutions in Kenya: A case of Kenya Post Office Savings Bank, International Journal of Business Management and Administration

Arto Kuusisto,(Ph.D Thesis 2000). Safety management systems: Audit tools and reliability of auditing. VTT Publications, Tempere University of Technology, Finland

Akpan, E. I. (2011). Effectively safety and health management policy of improved performance of organization in Africa, International Journal of Business and Management, Vol. 6, No.3

Babbie E. (2004). Basics of social research. 3rd Edition

Bhat, Zahid H.. (2013). Impact of training on employee performance: A Study of Retail Banking Sector in India, Indian Journal of Applied research 3. 10. 15373/2249555X/June 2013/97

Becker M.H. (1974). The health belief model and personal health behavior, Thorofam, NJ: Slack Press.

Burton J F Jr., Sengupta I and Reno V. (2008), Workers' compensation: benefit coverage and cost. Washington DC

Celine Fonkeng, (Thesis 2018). Effect of job stress on employee performance in an enterprise: A Microfinance institution in Cameroon. Centria University of Applied Sciences

Casio F. Wayne, (1992), Managing human resource: Productivity, quality of work life, profits, 3rd edition, New York: McGraw-Hill.

Cooper, M. and Cotton, D. (2000). Safety training a special case, Journal of European Industrial Training

Dan Autenrieth (2015), Occupational health and safety management system in animal production agriculture, Colorado- USA

David D. Woods, Laila Johnnesen, Sidney Dekker (2010). Behind human error, Ashgate Publishing.

Fakokunde T. (2000), Production and operation management. An introductory course, Cilncard Dimson Publisher, Osogbo.

Fernández-Muñiz B, Montes-Peón J. M., Vázquez-Ordás C. J. (2009). Relation between occupational safety management and firm performance, Safety Science 47 (980-991). Spain

Flick UWE, (2012). Introducing research methodology; A beginner's guide to doing a research project, Second Edition

Fowler J. Floyd Jr. (2013). Survey research methods (Applied Social Research Methods), 5th Ed.

Gary Dessier, (2012). Human resource management, Student value Edition (13th edition) 
Grace A. Ganson (2014). Assessing the effectiveness of health and safety practices at AngloGold Ashanti Company, Obuasi Mine. Ghana

Gyekye, S.A. (2010), Occupational safety management: The role of causal attribution. International Journal of Psychology, 45(6), 405-416

Hämäläinen P, Takala J and Saarela KL (2006). Global estimates of occupational accidents. Safety Science

Hital R. Meswani (2008). Safety and occupational health: Challenges and opportunities in emerging economies. Indina Journal of Occupational and Environmental Medicine

ILO (International Labour Organisation), (2003). Safety in numbers: Pointers for a global safety culture at work. Geneva, Switzerland

ILO, (2005). Promotional framework for occupational safety and health. Report IV (1), International Labour Conference, 93rd Session, Geneva

ILO, (2005). National health policy and strategy to achieve health for all, New York: ILO Publishers

ILO, (2012). Estimating the economic costs of occupational injuries and illnesses in developing countries: Essential information for decisionmakers.ILO, Switzerland

ILO, Encyclopaedia of occupation health and safety: Theory of accident Causes

Jilcha, Kassu and Kitaw, Daniel (2016). A literature review on global occupation safety and health practices and accidents severity, International Journal for Quality Research 10(2), 279-310

Karen A. Brown, P. Geoffrey Willis and Gregory E. Prussia (2000), Predicting Safe Employee Behavior in the Steel Industry: Development and test of a Socio-technical Model. Journal of Operations Management

Kimani, J. M. (Thesis 2011). Evaluation of occupational noise exposure among workers in metal fabricating sector in Kamukunji Nairobi. Jomo Kenyatta University of Agriculture and Technology

Koopman et al. (2002), Standford presenteeism scale: Health status and employee productivity. Journal of Occupational and Environmental Medicine .Vol. 44

Law regulating labor in Rwanda No 66/2018 of 30/08/2018

Mai Ngoc Khuong \& Vu Hai Yen, (2016). "Investigate the effects of job stress on employee job performance - A case study at Don Xuyen Industrial Zone, Vietnam" International Journal of Trade, Economics and Finance, Vol.7, No 2

Manikandan et al. (2017), occupational heat stress impacts on health and productivity in a steel industry in Southern India, Safety and health at work, Vol. 8

McCunney, R. (2001). Occupational health and medicinal J.

Meyer J.P. and Herscovitch, L. (2001). Commitment in the workplace: Toward a general model. human resource management review, Vol. 11

Meyer J.P. \&Allen, N.J. (1984). Testing the "side-bet theory" of organizational commitment: Some methodological considerations. Journal of Applied Psychology

MIFOTRA, (2012). Rwanda national occupational safety and health profile. Rwanda

Motowildo S.J. \& Borman, W.C. (1993). "Expanding the criterion domain to include elements of contextual performance". In personnel selection in organization, N. Schmitt and W.C. Borman, eds. San Fransisco: Jossey-Bass

Mowday R. T., Porter, L. W., \& Steers, R. M. (1982). Employeeorganizational linkages: The psychology of commitment, absenteeism, and turnover. New York: Academic Press

Muchemedzi, S., \& Charamba, L. (2006). National health and safety training course. NSSA. Harare

Muhamad Rizal, M.I. Syafile, Djumahir, R.M. (2014). Effect of compensation on motivation, organizational commitment and employee performance. A study of local revenue management at Kendari city. Vol. 3

Mugenda O. M and Mugenda A. G,. (2003). Research methods qualitative and quantitative approaches. Nairobi: Acts Press.

Norine et al. (Thesis 2016). The role of occupation health and safety measures in successful completion of construction project in rwanda: Evidence from Nyarutarama Property Developers Ltd. Kigali

Ofoegbu O.E., Olawepo G.T and Ibojo B.O (2013). Effect of occupational hazards on employees' productivity. European Journey of Business and Management, Vol. 5, No3

Omondi Oluoch Eric (2015), Effect of occupational safety and health programmes on employee performance at Kenya Power Company Limited

Opatha HHDNP (2012), Human resource management- personnel (Revised Edition), Author, Colombo

OSHA (2016), Recommended practices for safety and Health programs

Pandhe M. K, (2006). People's democracy Vol. XXX No 27 July 2002
Pilot, D.F. and Hungler, B.P (1995). Nursing research: Principles and methods. 5th Ed. Philadelphia: J.B. Lippincott Company

Radha Damle, (Ph.D. Thesis, 2012). Employee performance a function of occupational stress and coping: A study on Central Government Employees. Padmashree Dr. D.Y. Patil University, Mumbai

Rwanda Standards Board, DRS 291-1:2017, Accommodation and restaurant establishments

Ridley J. (1986). Safety at Work, Butterworths, 2nd edition

Raymond M. and Patmore G. (2011), Employee participation in health and safety in the Australian steel industry,1935-2006

Roberto G. Lucchini (2014). Global occupational health: Current challenges and the need for urgent action. Annals of Global health, Vol. 80

Sikpa Francis Cudjoe (2011). An assessment of occupational health and safety practices on job performance at the Tetteh Quarshie Memorial Hospital, Mampong-Akuapem

Shain M. (2016). The careful workplace: Seeking psychological safety at work in the Era of Canada's National Standard.

Sgroi Daniel, (2015). Happiness and productivity: Understanding the happy-productive worker. SMF-CAGE Global Perspectives Series

Steenkamp Rigard and AJ Van Schoor (2002). The quest for quality of work life: A TQM approach Juta and Company Ltd, Cape TownSouth Africa

Sundy Smith, (2010). National Safety Council's Journal, July 2, 2010

Tadesse T. and Kumie A. (2007). Prevalence and factors affecting workrelated injury among workers engaged in small and medium scale industries in Gondar Wereda, North Gondar Zone, Amhara Regional State, Ethiopia. Ethiopian Journal of Health Development

Valmae J. Dunlea, (Ph. D Thesis 2001). Occupational health and safety issues for small business in the Australian Hospitality Industry: A communication analysis. Queensland University of technology

Yankson Esi (Thesis, 2012). The effect of health and safety standards on productivity in Ghana Rubber Estates Limited, Institute of Distance Learning, Kwame Nkrumah University of Science and Technology

Yangho K, Jungsun P. and Mijin P. (2016). Creating a culture of prevention in occupational safety and health practice. Safety and health at work, Vol 7(2), PubMed Central PMCID: PMC4909854

Ward, J., Haslam, C. and Haslam, R.,(2008). The impact of health and safety management on organizations and their staff: Report submitted to the IOSH Research Committee. Institution of occupational safety and health (IOSH) and Loughborough University

Waweru J. Muthoga (Thesis,2012) An evaluation of occupational safety and health hazard awareness in Steel rolling Mills in Nairobi Metropolis. Jomo Kenyatta University of Agriculture and Technology.

WHO Regional Office for Europe, (1984). Health promotion: A discussion document on the concept and principles: summary report of the working group on concept and principles of health promotion, Copenhagen, 9-13 July 1984

WISHA Services Division; Washington State Department of Labor and Industries (2002), Office ergonomics: Practical solutions for a safer workplace. 